\title{
Risks and Threats for Economic Security in Forest-Based Sector, Generated by Possible Climate Changes
}

\author{
Artem V. Konstantinov ${ }^{1}$, Tatyana S. Koroleva ${ }^{1}$, Oleg I. Vasilyev ${ }^{1}$ \& Elizaveta A. Shunkina ${ }^{1}$ \\ ${ }^{1}$ Saint Petersburg Forestry Research Institute, Saint Petersburg, Russia \\ Correspondence: Artem V. Konstantinov, Saint Petersburg Forestry Research Institute, Institutsky pr., 21, \\ Saint-Petersburg, 194021, Russia. Tel: 7-812-552-8021. E-mail: konstantinov_a82@mail.ru
}

Received: April 20, 2015 Accepted: May 13, 2015 Online Published: July 15, 2015

doi:10.5539/ass.v11n20p134 URL: http://dx.doi.org/10.5539/ass.v11n20p134

\begin{abstract}
Due to expected climate changes, there is a forecast for arising of variety of interconnected and interdependent threats, leading to growth of risks in forest-based sector of economy.

Study of risk, as an economic category, has substantial significance for scientific and practical activity in forest-based sector, as it allows identifying the most dangerous threats for economic security.

This research includes the systematization of risk factors, caused by possible climate changes, with the allocation of the most dangerous ones which generate threats in forest-based sector of economy. Analysis of revealed risks is conducted on the basis of statistical methods of expert evaluation.

It has been established that most of threats for economic security in the sphere of forest use are related to climate change and have stochastic nature, which is determined by a large share of uncertainty of existing factors (air temperature, air and soil humidity, extreme weather phenomena). All of this significantly complicates the planning of work of forest relations members which in this case are the subjects of economic security.

The article emphasizes that the main problems of future forest-based sector will be caused by the change of forests productivity. Climate change, which could lead to forests' drying out, change of forest ecosystems, increase of the level of fires and broad-scale natural disasters will inevitably cause the difficulties in material and technical provision of forest-based sector and increase of expenses for all forestry operations. Consequently, there is a forecast for growth of risk factors in entrepreneurial activity, which will lead to risks of decrease of employment of population in forest husbandry, aggravation of labor conditions, reduction of profits of the sector, and decrease of employees' income. Economic and ecological consequences of climate change will have a vivid regional character.
\end{abstract}

Keywords: risk level, threats, social and economic security, forest-based sector

\section{Introduction}

Risks accompany any economic activity, but in forest-based sector they are most dangerous due to the difficulty of their complex evaluation with regard to indirect factors and factors that have long-term consequences.

Economic efficiency of forest economy supposes, as a rule, the quantity of production (products and services), manufactured by forests. These are economic indicators which can be easily measured; they are related to the results of forest industry work (Morkovina, 2014). In forest-based sector, besides influence of internal risk factors, caused by high level of unpredictability of results of forestry production, which, in its turn, is caused by long production cycle, technologies, and techniques of forestry works, the significant role belongs to external uncontrolled factors - primarily, natural, climate, and anthropogenous. In such cases, evaluation of efficiency of processes and probability of manifestation of risks often includes methods of indirect evaluation (FAO UN Global Forest Resources Assessment 2010; State of forests in Europe by 2011/ Short review for persons making decisions, 2011).

\section{Methods}

In order to allocate and analyze risks, caused by the influence of natural factors, the authors used the expert evaluation method, based on the survey of leaders of scientific and research organizations of forest-based sector. The respondents included five scientific-research institutes within the jurisdiction of Federal Forestry Agency. 
In order to process the results of survey and evaluation of risks and threats in the forest economy system, 2 criteria were chosen:

(1) result (value of consequences) of the risk manifestation (scale: from "minimal consequences" to "huge consequences");

(2) probability of risk manifestation (scale: from "manifestation is unlikely" to "constant manifestation").

For evaluation of risk values, the Harrington desirability scale was used, supplemented by verbal description of every interval of scale (Bezborodova, 2014). Evaluating such indicator, as risk level, it was supposed that (Morkovina et al., 2014):

- "critical risk level" corresponds to numerical value in the interval 1.0-0.8;

- "dangerous risk level" - numerical estimate $=0.79-0.60$;

- "acceptable risk level" - 0.59-0.40;

- low risk level 0.39-0.2;

- insignificant risk level 0.19-0.0.

Evaluation of consequences and probability of realization of risks was performed by expert method, using the following formulae:

$$
P n \quad i_{i}=\frac{\sum_{J=1}^{N} P n \quad i j}{N}
$$

where, $P n$ - risk consequences of realization of $i$-risk;

$\mathrm{P}_{\mathrm{ij}}$ - risk consequences of realization of $i$-risk, according to $\mathrm{j}$-expert evaluation;

$\mathrm{j}-$ No. of expert (from 1 to $\mathrm{N}$ ).

$$
P B_{i j}=f\left(P n_{i} \cdot W_{i}\right)=\frac{\sum_{j=1}^{N} P n_{i j} \cdot W_{i j}}{N}
$$

where $P s_{i j}$ - evaluation for probability of manifestation of i risk by expert No. $\mathrm{j}$.

Wij- probability of manifestation of i risk, according to expert No. j.

Based in the study of factors that determine the emergence of risk situations, there was performed a systematization of risks with allocation of the most dangerous ones, which generate threats in forest-based sector of economy.

Informational basis for analysis and allocation of tendencies consisted of the data of Ministry of Natural Resources and Ecology of the Russian Federation, Government reports on the state of natural environment, state and use of forest resources, development of forest economy and forest management in the Russian Federation.

\section{Results}

Study of risk, as an economic category, has a substantial significance for scientific and practical activity in forest-based sector, as it allows identifying the most dangerous threats for economic security.

Most of the threats for economic security in the forest economy sphere, caused by climate change, have stochastic nature, which is determined by a high level of uncertainty of existing factors (air temperature, air and soil humidity, extreme weather conditions). This largely complicates the planning of work of members of forest relations, which are, in this case, the subjects of economic security (Konstantinov, 2014).

For classification of threats for economic security of forest husbandry sphere under conditions of anthropogenous change of climate, the following functional constituents are allocated: change of forest productivity, biodiversity, water resources, increase of the risk of natural fires, diseases, and forest pests, extreme weather conditions, socio-economic and institutional component (Table 1).

Multidimensionality of the risk of forest husbandry under the condition of change of natural and climate situation causes the possibility for its many interpretations - firstly, as uncertainty of losses and income, and secondly, as probability (threat) of loss by the real sector of economy of the part of resources, loss of revenue, or emergence of additional expenses as a result of chosen policy. 
Table 1. Classification of threats for economic security in the sphere of forest economy under conditions of anthropogenous change of climate

Functional components of economic security

Names of threats for economic security

Change of forest productivity

Decrease of forest productivity, caused by change of temperature and air humidity, leading to reduction of their material and financial assessment

Increase of forest productivity, caused by change of temperature and air humidity, leading to growth of their material and financial assessment

Changes of life status of species on the administered territories, leading to decrease of

Changes in the level of investment attractiveness of forest ranges

biodiversity

Implementation of migrating species on the administered territories

Fragmentation of administered territories

Lack of water, water stress, and increase of drought, decrease of crop yield of

Changes in accessibility of water agricultural lands due to desertisation of territories resources

Rise of humidity and changes in seasonal patterns of falls, decrease of crop yield of agricultural lands due to mire formation

Increase of risk of natural fires in forests

Increase of risk of massive distribution of pests and forest diseases

Increase of risk of emergence of extreme weather conditions

Changes in socio-economic and institutional conditions

Rise of the number, frequency, and size of natural fires in forests, leading to reduction of volume of forest resources and timber harvesting, outflow of enterprises and labor resources from the sphere

Rise of number of outbreaks of massive breeding of insects, pathogens, and invasive types, leading to decrease of quality of forest resources, volumes of timber harvesting, and value of forest

Rise of the frequency and intensity of floods

Rise of frequency and intensity of storms

Rise of frequency of late autumn and prevernal frosts

Changes in sectorial markets

Rise of risk of economic losses

Development of shadow market of timber

Table 2. Systematization of risks in the system of forest husbandry

\begin{tabular}{|c|c|}
\hline Complex risks & Simple risks \\
\hline \multirow{8}{*}{$\begin{array}{l}\text { Political and } \\
\text { law risks }\end{array}$} & Risk of limiting export of products and resources \\
\hline & $\begin{array}{l}\text { Risk, caused by actions of authorities: confiscation of assets, termination of contracts, cancellation of } \\
\text { licenses }\end{array}$ \\
\hline & Risk of nonpayment from government buyers and customers \\
\hline & Risk of unfavorable change of tax legislation \\
\hline & Risk of administrative barriers, constant revisions, and corruption \\
\hline & Risk of unreasonable growth of requirements from management bodies of forest husbandry \\
\hline & Risk of unstable economic situation (inflation growth) \\
\hline & Risk of unfavorable change of forestry legislation \\
\hline \multirow{8}{*}{$\begin{array}{l}\text { Productive-eco } \\
\text { nomic risks }\end{array}$} & Risk, caused by sale of finished products or service rendering \\
\hline & Risk of the growth of rent \\
\hline & Risk, caused by organization of manufacturing process \\
\hline & Risk of technological process \\
\hline & Risk, caused by growth of prices and tariffs for services of third parties \\
\hline & Risk, caused by high interest rates on loans; investment risks \\
\hline & Risk of investment limitation and low attraction of forest husbandry \\
\hline & Risk of underdevelopment of transport infrastructure \\
\hline \multirow{7}{*}{$\begin{array}{l}\text { Natural and } \\
\text { climate risks }\end{array}$} & Risk of forest fires \\
\hline & Risk, caused by weather and climate changes \\
\hline & Risk of breeding of insects and forest pests \\
\hline & Risk of harm dealt by wild animals \\
\hline & Risk, caused by unfavorable weather conditions, windfall, flood \\
\hline & Risk of increase of anthropogenous stress \\
\hline & Risk, caused by long production cycle \\
\hline
\end{tabular}


Variety of risks in the system of forest husbandry under condition of possible climate changes is reflected in Table 2. At that, the number of complex risks, together with natural and climate, include the regulatory and law group and productive-economic group. Each complex risk, in its turn, was represented by variety of simple risks.

For purposes of the research, the special emphasis was made on the evaluation of natural and climate risks for forest-based sector of economy.

Climate warming leads to the risk of substantial loss of biodiversity (Klaptsov, 2012) due to change of reproduction cycles of animals and plants and/or migration of animals, length of vegetation period, distribution of species and size of populations, or even extinction of species in many forest regions due to reaching the warm limit of the suitable area of circulation. This relates to substitution of some tree species by other - as a rule, less valuable - reduction of net productivity of ecosystems and biomes, domination of opportunistic, "agrestal" species (IPCC Fourth Assessment Report, Climate Change, 2007; Edwards et al., 2005).

In the forests, where the main task is timber production, strong storms can create big problems of economic, ecological, and social character, and, together with fires, are, probably, the most significant and large-scale type of intrusion into product value of timber stand both in natural and administered forests. Drying-out of forests inflicts a lot of damage to forest husbandry and creates background for emergence of catastrophic forest fires (Global change of climate and its manifestations and consequences for Russia: socio-economic and ecological aspects. Review of the most significant publications in Russian, 2005).

Reduction of length of winter season due to warming leads to reduction of timber harvest period in the forest. Reduction of seasonal durability of winter roads, in its turn, leads to problems with transportation, including all-terrain transport. Consequently, it leads to significant violation of plant cover, impossibility for use of old track, and need for a new road. Except for ecological damage with soil disturbance on large territories, large financial expenses for new roads are expected.

Sporadic outbreaks of pest activity can have negative consequences for growth and length of tree life, crop yield, and quality of woody and non-woody forest products, environment of wild animals and plants, and also recreational, aesthetic, and cultural value of forests. In some cases, outbreaks of quantity of pests threaten the trade of forest products, reduce the product value of timber, and lead to loss of revenue and direct economic losses (FAO UN Global Forest Resources Assessment, 2010).

In whole, the situation can lead to reduction of forest territories with valuable tree species (Edwards et al., 2005; ACIA, Arctic Climate Impact Assessment, 2005), which will cause economic losses of raw timber exporters and consumers and difficulties for timber processing industry. The situation can lead to increase of social tension in the population employed in forest and timber processing industry.

As a result of processing of statistical information, received during expert survey of respondents, the expert evaluation of the level of risk, significance (rankings) of revealed risk factors, and values of indicators of risk factors was conducted.

It was found that the most dangerous risks for forest-based sector are natural and climate complex risks, which can be presented as variety of simple risks, caused by increase of the number, frequency, and size of natural fires in forests; increase of anthropogenous pressure and massive distribution of pests and forest diseases (Table 3).

Table 3. Critical risks in forest-based sector

\begin{tabular}{|c|c|c|c|}
\hline Risk factor & $\begin{array}{c}\text { Evaluation of factor } \\
\text { importance (value of } \\
\text { consequences) }\end{array}$ & $\begin{array}{l}\text { Evaluation of frequency of } \\
\text { manifestations (probability) }\end{array}$ & $\begin{array}{c}\text { Final } \\
\text { evaluation of } \\
\text { risk } \\
\end{array}$ \\
\hline $\begin{array}{l}\text { Risk, caused by increase of the number, } \\
\text { frequency, and size of natural fires in } \\
\text { forests }\end{array}$ & 0.92 & 0.86 & 0.89 \\
\hline $\begin{array}{c}\text { Risk of increase of anthropogenous } \\
\text { pressure }\end{array}$ & 0.96 & 0.80 & 0.88 \\
\hline $\begin{array}{l}\text { Risk of massive distribution of pests and } \\
\text { forest diseases }\end{array}$ & 0.94 & 0.72 & 0.83 \\
\hline
\end{tabular}

It should be noted that occurrence of above mentioned risks in the forest-based sector possesses not only critical, but sometimes catastrophic consequences. 


\section{Discussion}

Over the last 50 years, there has been a quick increase of expenses in forest-based sector of economy, caused by extreme weather conditions. Global economic losses due to catastrophic events increased by 10.3 times, beginning from 1950s (IPCC Third Assessment Report, Climate Change, 2001).

Economic literature of recent years, devoted to problems of risk, gives the classification of risks with allocation of four spheres of their manifestation: productive, commercial, financial, and innovational (Baldin, 2006). At the same time, study of risks and their consequences in forest-based sector appears to be of great interest (Morkovina et al., 2014).

Natural forest ecosystems are especially vulnerable from the point of view of climate change. The expected climate changes can violate the stable relations between tree species at the stage of natural restoration of forests after cuttings and fires, and in the centers of forest disease and pests. Most of researchers agree that in the long-term the expected changes of temperature can lead to shift towards the north of the boundaries of climate zones. Air temperature increase and related decrease of soil moisture content will lead to gradual disappearance of boreal forests and substitution of tropical forests by savannas. There will be a tendency for substitution of plants of semiarid region by plants of arid region.

Despite the fact that consequences of climate change for forest productivity manifest themselves slowly, they will be seen after a long period of time, while some changes can be irreparable (IPCC Fourth Assessment Report , Climate Change, 2007; Williamson et al., 2009; Smith et al., 2009; Perspective research on forest-based sector of North america for 2006-2030. Geneva research on forest husbandry sector and forest industry № 29, 2012; Olsson, 2013; Olsson, 2009).

The main problems refer to the productivity of forest husbandry. Change of climate, which can lead to drying-out of forests, change of forest ecosystems, and shift of forest areas will lead to difficulties in material and technical provision of forest-based sphere and rise of expenses on all forest husbandry operations - from taxation to timber harvest and timber transportation. The making of new roads will be necessary.

Consequences of climate change will influence market sector, which will lead to change of volume, quality, and prices for timber, other products and services. The share of forest-based sector, including timber processing and production of paper and cellulose constitutes approx. 1\% of the total gross product of European countries. However, as a result of above mentioned negative consequences of climate change, the situation can significantly change (State of forests in Europe by 2011/ Short review for persons making decisions, 2011; Geneva research on forest husbandry sector and forest industry № 32, 2013).

Besides, the influence on the market will be expressed in change of demand for energy products made of timber, in change of transport accessibility of forest-based sector of economy, tourism and building on the basis of raw timber, in increase of material damage and insurance loss as a result of extreme climate phenomena, in necessity for decision making regarding the location and change of location of objects of development and population, in change of need for resources, and in rise of cost of measures for adapting to the climate changes. Consequently, there will be reduction of employment in forest-based sector, aggravation of labor conditions, reduction of profitability, and decrease of employees' income.

Climate change and expected changes of events related to weather, which, as is believed, are caused by climate change, will raise the insurance uncertainty for evaluation of risk in forest-based sector and related industries.

Beliefs that some states, including Russia, will receive profits from global warming are, according to variety of scientist, not true; it is proved when taking into account local damages from accidental fluctuations of climate system and cases of extreme weather conditions, and also damages of global character.

At that it should be noted that influence of climate in economic aspects of forest husbandry could have direct and indirect character. Consequences of direct influence include real and expected changes of conditions of husbandry, determined by vulnerability of economy in whole and its certain industries to climate fluctuations. At the macro-economic level, it is manifested in change of dynamics, structure, and technological mode of economy. Indirect consequences are caused by reaction of economic system to these changes: weakening of husbandry influence on climate forcing or adaptation of main elements of economic system to new circumstances. It should be noted that changes of husbandry conditions could both aggravate the development of specific industries and territories and facilitate it (IPCC Third Assessment Report, Climate Change, 2001). 


\section{Conclusion}

Risks and threats for economic security of forest-based sector under condition of possible climate changes were assessed with the use of content analysis. Based on the systematization and analysis of the data of literary sources and on the processing of results of survey, the main risks for economic security of forest-based sector were found which are specific for it (i.e. requiring special methods of management), and the nature of which is largely determined by the peculiarities of the sector itself.

It was found that the most dangerous risks for forest-based sector are natural and climate complex risks, which can be represented as variety of simple factors, caused by increase of burns, frequency and size of natural fires in forests; increase of anthropogenous load and massive distribution of pests and forest diseases. The conducted numerical estimates of probability and size of consequences of above mentioned factors for forest husbandry show that they lie in the interval that corresponds to the critical risk level.

In this situation, the task of development of conduct of measures, aimed at the easing of consequences of climate change for forest-based sector and increase of sustainability of forest plants becomes more significant. Development of the strategy for adaptation of the system of forest husbandry to possible climate changes is also important.

\section{References}

Baldin, K. V. (2006). Risk management (p. 368). Eksmo.

Bezborodova, T. I. (2014). Using Harrington function for ranking score of work of organization under conditions of anti-crisis management. Financial analytics: problems and solutions (No. 1).

Edwards, M. E. et al. (2005). Structurally novel biomes: A response to past warming in Beringia. Ecology, 86(7), 1696-1703. http://dx.doi.org/10.1890/03-0787

FAO UN Global Forest Resources Assessment 2010. Main report. Food and Agriculture Organization of the United Nations (p. 335). Rome 2010. Retrieved from http://www.fao.org/docrep/013/i1757e/i1757e00.htm

Geneva research on the sphere of forest husbandry and forest industry №32. Lviv forum "Forests in "green economy" for countries of Eastern Europe, North and Central Asia (p. 80). UN. Geneva, 2013.

Global change of climate and its manifestations and consequences for Russia: socio-economic and ecological aspects. Review of the most significant publications in Russian, 31 c. Retrieved from $\mathrm{http} / / /$ esco.co.ua/journal/2005_8/art30.pdf

IPCC Fourth Assessment Report, Climate Change 2007 (AR4), Geneva, Switzerland (p. 104).

IPCC Third Assessment Report, Climate Change 2001 (TAR), Geneva, Switzerland (p. 220).

Juday, G. et al. (2005). ACIA, Arctic Climate Impact Assessment 2005 (Chapter 14: Forests, Land management and Agriculture).

Klaptsov, V. M. (2012). Ecological systems of sustainable development. Report at the meeting of expanded scientific council of Russian Institute of Strategic Research, 27.09.2012. Retrieved from $\mathrm{http} / / /$ www.riss.ru//analitika/198-ekologicheskie-problemy-ustoychivogo-razvitiya?print=1

Konstantinov, A. V. (2014). Role and place of anthropogenous climate change in the system of provision of economic security in economy sectors. Socio-economic phenomena and processes, 9(8), 61-66.

Morkovina, S. S., Popkova, E. G., Santalova, M. S., \& Konstantinov, A. V. (2014). Development of methodological approaches to the efficiency analysis of territorial-industry cluster formation in the forest sector. Asian Social Science, 10(23), 85-94. http://dx.doi.org/10.5539/ass.v10n23p85

Morkovina, S., Popkova, E., Panyavina, E., \& Ivanova, A. (2014). Entrepreneurial risk as consequence of contradictions of economic interests in forestry in Russia. Review of Applied Socio-Economic Research, $7(1)$.

Olsson, R. (2009). Boreal Forest and Climate Change the Air Pollution \& Climate Secretariat \& Taiga Rescue Network. Air pollution and climate series, 23.

Olsson, R. (2013). Use or protect? Boreal forests and climate change. Sustainable forest use, 2(35), 36-45.

Perspective research on forest-based sector of North america for 2006-2030. Geneva research on forest husbandry sector and forest industry №29. Publishing Service, United Nations, Geneva. - 77 c.

Smith, W. B., Miles, P. D., Perry, C. H., \& Pugh, S. A. (2009). Forest Resources of the United States, 2007. 
General Technical Report WO-78, USDA Forest Service, Washington, D.C.

State of forests in Europe by 2011/ Short review for persons making decisions. Stable forest use, 3(28), 2-7.

Williamson, T., Colombo, S., Duinker, P., \& Gray, P. (2009). Climate Change and Canada's Forests: From Impact to Adaption. Sustainable Forest Management Network, Natural Resourses Canada, Canadian Forest Service, Ottawa, Ontario.

\section{Copyrights}

Copyright for this article is retained by the author(s), with first publication rights granted to the journal.

This is an open-access article distributed under the terms and conditions of the Creative Commons Attribution license (http://creativecommons.org/licenses/by/3.0/). 